LUBLIN STUDIES IN MODERN LANGUAGES AND

LITERATURE 41(1), 2017, HTTP://WWW.LSMLL.UMCS.LUBLIN.PL, HTTP://LSMLL.JOURNALS.UMCS.PL

Ferit Kılıçkaya

Department of Foreign Language Education

Mehmet Akif Ersoy University,

İstiklal Campus, Burdur, Turkey

ferit.kilickaya@gmail.com

Mustafa Zeki Çıraklı

Department of Western Languages and Literature

Karadeniz Technical University,

Kanuni Campus, Trabzon, Turkey

mzcirakli@gmail.com

\title{
Lenses on English Literature and Teaching English - From the guest editors
}

This special issue "Lenses on English Literature and Teaching English" of Lublin Studies in Modern Languages and Literature (formerly Lubelskie Materiaty Neofilologiczne) brings together selected papers presented at the $5^{\text {th }}$ International Conference on Language, Literature and Culture, held on May 1-4, 2016 in Burdur, Turkey. The conference was sponsored by Mehmet Akif Ersoy University in cooperation with Çankaya University and Süleyman Demirel University. The conference included a variety of presentations by participants from different countries and featured keynote addresses by Jarosław Krajka (Poland) and Beture Memmodova (Turkey). The conference was devoted to language, 
literature, and culture, with the main aim to provide a forum for discussion and to facilitate integration in these fields and to bring together researchers, scholars, and students from all areas of language, literature, culture, and other related disciplines from all around the world. We would like to express our deepest gratitude to all the authors and the reviewers for their timely work and to our colleagues, Jolanta Knieja and Jarosław Krajka for their invaluable support and contribution.

The very first article in this special issue is Ammar Sh. K. AlKhafaji's "A Study of Suffering and Martyrdom in Islamic Ta'ziya and Christian Passion Plays", which depicts the representation of the recurrent themes of suffering and martyrdom in the myths of the ancient West and Near East, with historical references and repeated patterns of the stories. The study shows that the counterpart of the Christian Passion plays in Islamic tradition is the "Ta'ziyeh" drama or Condolence Theatre. The commemoration of the sacrificial acts of Christ and Imam Hussein is observed as to highlight a common characteristic of human dignity. Even though the paper argues that the latter is a mere sacrifice for divinity, both underline an agonizing yet holy celebration of the mode: vita in divina mortis.

Hakan Gültekin and Mustafa Zeki Çıraklı's "Pause as a Discursive Element in Hemingway's Selected Short Stories" presents an investigation of the discursive elements of pause and turn-taking. The study, carrying out a linguistic analysis, questions whether the patterns of these discursive elements are in consistent with the underlying themes of the stories. The study provides the reader with palpable evidence that there is a relationship between linguistic devices and recurrent themes pertaining to the prevailing motif of silence.

Mustafa Zeki Çıraklı's "Disabled Vision and Schizophrenia in Toni Morrison's The Bluest Eye" provides an alternative reading of Morrison's fiction. Çıraklı, with reference to Foucault and Lacan, problematizes the construction of Self and attempts to postulate a relatively novice term called "primary Subject". Exploring the underlying matrix of passivity and the issue of negative self-image, 
the paper analyzes how the primary Subject orients social perception, determining in effect self-perception. Concerning the prevailing primary Subject and the obliteration of a point of reference (selfperception), the paper gives the impression that it allegorizes Bloom's narrative for further representation of social structures.

Serkan Ertin investigates the generic aspects in "Parody of Detective Fiction in Muriel Spark's Not to Disturb," and explores the elements of Burlesque in relation to the issue of parody. The study, analyzing the fictional elements of the narrative, reveals that Spark's novel presents the reader with a dazzling attempt of parody and invites the reader to hold an inquiry into the parodied puzzle of a so-called detective story.

"The Magic Toyshop as Nucleus of Desire: A Lacanian Analysis" by Serkan Ertin and Özlem Türe Abacı draws attention to Angela Carter's The Magic Toyshop. The paper reads the narrative according to Lacan's terminologies. The paper demonstrates how the primordial father, the representative authority figure in the story, enforces Law as such, and hardly tolerates digression or transgression from the Law. This paper is interesting in that it well represents the oscillating mutual denoument of "desire and Law," which provides the impetus behind the developing incidents.

Gizem Kaptan's "The Analysis of Social Stratification in Elizabeth Gaskell's Mary Barton: A Tale of Manchester Life from a Marxist Perspective," with regard to the historical background of Industrial Revolution and Marxist Manifesto, deals with how the capitalist system afflicts misery on the working class as well as how class conflict is represented in the fictional story world of the narrative. Even though the argument sounds familiar, the study provides a useful example of Marxist reading of a Victorian novel.

Beture Memmedova, in her "The Touch that Always Does Wonders," makes reference to Harold Bloom's pessimistic impressions of the prospective literary studies and teaching literature in the future and foregrounds the current debates as to literary canon and classical works. The author questions whether they are to lose their influence disappearing off the reliable stage of impact. The paper 
discusses Bloom's prophetic yet elegiac conclusions about the future of the institutions regarding the transformation of the literary into the cultural or primacy of literary "ologies" rather than "isms," and highlights the concerns raised by Bloom, also stressing the degeneration in the aesthetic value of literary works particularly after the rise of postmodernisms and popular culture. In its concluding section, the paper seeks to imbue some sense of hope, though.

Fatma Yalvaç and Şule Okuroğlu Özün deal with Shakespeare's The Merchant of Venice and Measure for Measure with a specific focus on the concept of justice and the depiction of the courts in Shakespearean drama. Shakespearean court is presented as having a two-fold nature: it represents a social institution as well as posing questions on its effects on society. The paper elaborates on the intricacies exhibited by the acts of legal authority figures in each play, and debates upon controversies regarding the concept of justice and its dramatic representation.

In the study titled "Wedding Invitation Genre: Communicating Sociocultural Identities of Iraqi Society", Nassier A. G. Al-Zubaidi provides an analysis of Iraqi wedding invitation cards based on textual and visual components as well as the social norms and assumptions. A sample of 250 wedding invitation cards has been selected and analyzed for content analysis. The study reveals interesting findings regarding how these cards are created to achieve communicative as well as social functions of the wedding ceremonies. The sociocultural and religious assumptions as well as the conventions of the local society have been found to affect this communicative function, together with the Islamic ideology depicted clearly in the visual elements.

In his contribution titled "The Age of the Narrator and the Qualities of the Narrative Constructed", Mehmet Özcan analyzes stories produced by children, adults, and older people based on several factors such as sentence structures and Mean Length of Utterance. Özcan focuses on both narrativeness quality of the texts provided by the participants and the construction quality based on different age groups. The data were collected through asking the participants to 
read and tell a textless picture book, "Frog, where are you?". The results indicated that the narratives of the story indicated significant differences in terms of qualitative and quantitative perspectives compared to those of adults and older participants.

Astrid Ebenberger's contribution, "Developing Individual Language Competences via Task-Based-Learning (TBL) and Content and Language Integrated Learning (CLIL)", points out the importance of selecting work and activities based on children's needs based on differentiation and individualization since the current classrooms are not considered 'stable' or 'fixed' in terms of diversity. To this end, Ebenberger defends the idea that TBL and CLIL are appropriate didactical approaches to deal with diversity in the classroom and provides selected lesson plans created by students that have participated in a workshop on differentiation and individualization. Although much time is required regarding the preparation of the materials, several advantages are voiced such as increased motivation.

In their study "Learner Perspectives on Mobile Phone Integration for Vocabulary Development in Translation Classes", Mustafa Naci Kayaoğlu, Hasan Sağlamel, and Mustafa Kerem Kobul investigate learners' perceptions of the effects of mobile technologies integrated into vocabulary development practices in translation classes at an English Language and Literature department in Turkey. Benefiting from a content analysis of semi-structured interviews with twentyseven students in the department, the authors indicate that the participants have positive attitudes towards the use and integration of mobile technology into the classroom. The findings especially point out the importance of providing medium-rich content to learners as it appeals to todays' learners with different learning styles and needs.

Finally, Mustafa Şevik's study "An Investigation of ELT Student Teachers' Dictionary Ownership and Preferences" focuses on ELT student teachers' ownership and preferences regarding the use of paper and electronic (CD/DVD or online) dictionaries at Mehmet Akif Ersoy University in Turkey. Collecting the data based on the questionnaire adopted through several previous studies, the author attempts to investigate the student teachers' beliefs and practices. The 
results indicate that the participants tend to move away from paperbased dictionaries to electronic ones due to several reasons such as easy and quick access to information, which we believe is one of the most important contributions of technology to the field.

We wish you good reading! 